\title{
FINANCING GREEN INFRASTRUCTURE DEVELOPMENT AND MAINTENANCE IN ADDIS ABABA CITY, ETHIOPIA
}

\author{
Tafa Mosisa Ijara \\ Department of accounting and finance, Ethiopian Civil Service University, Addis Ababa, Ethiopia \\ DOI: 10.46609/IJSSER.2020.v05i11.025 URL: https://doi.org/10.46609/IJSSER.2020.v05i11.025
}

\begin{abstract}
The importance of green infrastructure for human health, recreation, response to climate change, as a means of protecting natural habitats and biodiversity is recognized worldwide. Due to this importance green infrastructure need to be accessible to all people uniformly at the required quantity and quality. However the green infrastructure in Addis Ababa city is inadequate. This study focuses on the financing green infrastructure development and maintenance, as finance is one of the critical. To conduct this study a descriptive type of research was designed by applying mixed research approach. The data were collected from both primary and secondary sources using face to face interviews with six officials, and reviewed of the organization reports and other records. The quantitative data were analyzed using descriptive statistics and the qualitative data were narrated systematically. Then the result of the study shows that the current green infrastructure status of the city is 0.25 squares meter per person and with poor quality, though the national and world health organization standard is 15 and 9 square meters per person respectively. The major reasons for the inadequacy includes; the city government weak commitment, shortage of finance and weak performances of the agency. Financing for green infrastructure was obtained mainly from public sources and only lesser amounts were obtained from private businesses and households. There was almost no new source of finance used over time. Therefore study found the potential sources of finance such as participation of stakeholders, service charges, revenue from sponsorship and the management of sports facilities, cafeteria, restaurants, and shops among others. Hence, this study suggests that the agency and city administration should look into the new innovative sources of finance such as that identified in the study results.
\end{abstract}

Key words: Addis Ababa, Financing, Green Infrastructure 
International Journal of Social Science and Economic Research

ISSN: 2455-8834

Volume:05, Issue:11 "November 2020"

\section{Introduction}

Recently, the value of green infrastructure in urban area is increasingly recognized by health professionals, water managers, planners, policy makers and designers around the world. The rapid expansion of towns and cities contains the real risk of creating unlivable and unhealthy environments by reducing green spaces, parks, forests, increasing carbon emissions and wastes (Martin and Sheryn 2012). To invest and manage the infrastructure the city should have efficient and effective financial system. Infrastructure financing method around the world has shown tremendous changes in the past decades. In support of this Merket el. (2012) and CABE (2006) their study has found various method of finance for the green infrastructure in European countries and United States of America.

Public service provision in urban infrastructure is associated with high levels of inefficiency, a lack of innovation, and especially in developing and transitional countries low levels of coverage, favoring richer neighborhoods and neglecting the interests of poor households (Johnstone and Wood 2001). Proponents of public sector participation for instance World Bank, and Organization for economic co-operation and development argue that private involvement can improve efficiency, provide better quality, help extend public service delivery, and increase population coverage by raising private investment finance and relieving governments of budget deficits (Estache and Rus 2000). Despite the limited examples of private-sector led green infrastructure projects to date, there are a growing number of examples of successful publicprivate partnership models of delivery - particularly between private companies and urban/municipal authorities (David and Matt 2015).

Across developing and emerging markets, currently the greatest majority of funding for infrastructure comes from public sources. This is not sustainable, given the scale of global needs and the increasing pressure on government budgets. Around $80 \%$ of the estimated US\$ 1 trillion a year of additional investment will probably need to come from private sources (United Nations environment program, European bank, and Reinvesting Bretton woods committee 2016). Infrastructure contributed 0.6 percentage points to Ethiopia's annual per capita GDP growth over the last decade. Increasing the infrastructure contribution level of the country to the level of region's middle income countries could raise annual growth by an additional 3 percents (Vivien and Elvira 2010).

Green infrastructure projects, whilst providing a range of ecosystem service benefits, often entail a substantial range of costs. Financing challenges include substantial upfront capital costs and their ability to contribute to cost savings and revenue generation (David and Matt 2015).

African countries face several constraints regarding infrastructure development and maintenance, 


\section{International Journal of Social Science and Economic Research}

ISSN: $2455-8834$

Volume:05, Issue:11 "November 2020"

including deficiencies in planning, poor management of existing infrastructure assets, institutional inefficiencies and regulatory bottlenecks, and inadequate financing for project preparation and implementation (Mthulin.d). Ethiopia faces one of the more challenging infrastructure situations of any country in Africa. Addressing Ethiopia's infrastructure deficit will require a sustained annual expenditure of $\$ 5.1$ billion over the next decade. This level of investment is well beyond what the country can afford, however, as it represents more than 40 percent of GDP and is three times the already impressive infrastructure spending of around \$1.3 billion that the country managed during the mid-2000s (Vivien and Elvira 2010).

Addis Ababa (Finfinne) city is the capital of federal government of Ethiopia and Oromia regional state. City administration plan to achieve $0.5 \mathrm{~m} 2$ green infrastructures per capita in GTP II, while the national standard is $15 \mathrm{~m} 2$ per capita and this indicate future investment is expected to be high. To have the efficient and effective infrastructure investment the mechanisms of financing is the most important factor. However the agency mostly focuses on the traditional method to finance green infrastructure. This problem limits the activities needed to be undertaken to achieve green infrastructure objective. Therefore looking to the innovative (potential) source of financing for green infrastructure is essential to overcome the Problem. As far as the literature reviews are conducted the previous studies were emphasized on the assessment of the green infrastructure investment and availability. However studies were not conducted on the green infrastructure financing in the country, so undertaking a study on the innovative financing for green infrastructure in city would fill the existing study gap and come with the new ways of solving the financing problem. Therefore, the aim of this study is to investigate the mechanism of financing the green infrastructure in Addis Ababa (Finfinne) city by evaluating the current situation of the green infrastructure financing.

The next section of this paper is organized as follows. Section two focuses on the review of the related literature, section three presents methodology of the study; section four presents study result and discussion and Section five presents a conclusion and recommendations of the study.

\section{Literature review}

\subsection{Demand, Benefits and Costs of urban green infrastructure}

The demand for urban green space can be roughly approximated by the number of urban population. The application of per capita urban green space values and accessibility threshold values can provide a broad overview-kind of assessment of green space provision for a whole city without looking into the inner differentiation of the city itself (Larondelle and Haase, 2013). The green space demand is not only in its quantity rather its quality, so that the quality of green spaces at a given time is very important. 


\section{International Journal of Social Science and Economic Research}

ISSN: $2455-8834$

Volume:05, Issue:11 "November 2020"

Accesses to good urban green spaces have various benefits to the human population and the environment in general. Research shows that access to urban green space can have great impact on human health in terms; enhance psychological wellbeing, promote physical activity and improve the general public health of urban residents (Wolch et. al., 2014). In addition to these important components, Mitchell and Popham(2007) argue that people who live near green spaces are healthier than people who live farther from green spaces.

Parks as one form of urban green space it is a space where people can relax or exercise and parks improve air quality and in general help to improve the environment because parks have vegetation (Parsons2015). However, loss of natural landscape and green space due to rapid urbanization is occurring and might be detrimental to human health (Coutts et. al., 2010). To ensure green spaces are distributed equitably within a city, a measuring system needs to be developed and implemented.

Cities spend between $10 \%$ and $45 \%$ of total urban expenditures in sectors with green potential. This means that cities have a relatively large margin of maneuvering for greening these sectors (transport, building, water, waste and other environmental services). The margin is particularly high in Canadian cities like Montreal and Toronto, where they represent $44 \%$ of total city current and capital expenditures, mainly due to large shares in transport spending. These expenditures can stimulate green growth through employment opportunities: in the short term, during the construction phase of the infrastructure, and in the medium/long term, in maintenance or transport. Green spaces, parks management, environmental services, streets and sanitation, power and environmental protection can also present green growth opportunities generally related to regular maintenance of green spaces or streets (Merket. el. 2012). Investing in green urban infrastructure is challenged by current global fiscal constraints. Resources are scarce, and public authorities in all levels of government must do more with less. At the same time, global infrastructure needs are huge. According to OECD (2007), improving the world's infrastructure will require an estimated USD 35-40 trillion - i.e. USD 2 trillion dollars per year, or 2.5\% of global GDP (IEA 2011).

The urban infrastructure deficit in developing countries is particularly acute. A high proportion of the urban population in Africa and Asia, and a significant proportion in Latin America and the Caribbean, live in homes and settlements with little or no infrastructure. Removing the housing and infrastructure deficit in developing countries by 2030 would cost an estimated USD 6.3 trillion, including USD 700 billion for expanding housing and infrastructure for growing urban populations (Parry et. al., 2009). Greening urban systems is expensive and requires shifting of investments. Preliminary estimates of C40 (Cities Climate Leadership Group) city greenhouse gas emissions suggest that the total capital costs of infrastructure investments required to 


\section{International Journal of Social Science and Economic Research}

ISSN: $2455-8834$

Volume:05, Issue:11 "November 2020"

mitigate the group's emissions, status quo (i.e. without population growth), would be approximately USD 3 trillion(Hoornweget al., 2011). Investment of this scale calls for a new focus on green funding and innovative solutions. A range of instruments can help to achieve green infrastructure goal through green urban finance and innovative finance solutions.

\subsection{Sources of finance for green infrastructure}

Private financing could be one of the solutions to fill the funding gap for many urban green infrastructure projects. For private finance to be a solution, three conditions would have to be met: a market for green urban investment projects, good return on investment and limited risk. Several instruments can be applied to attract private finance for urban green infrastructure. Private sector involvement in urban green infrastructure can take the form of public-private partnerships (PPPs), whereby the long-term risk is transferred to the private sector. Another instrument, tax increment financing, uses tax revenues to attract private finance (Merk et al., 2012). The public-private partnership is formed under different contractual agreements which are characterized by different risk-sharing and financing schemes, different organization forms (OECD 2008).

Cities throughout the OECD and municipalities across North America levy development charges or impact fees to pay for infrastructure in new developments. A development charge is a onetime levy on developers to finance the growth-related capital costs associated with new development or, in some cases, redevelopment. These charges are levied for works constructed by the municipality, and the funds collected must finance the infrastructure needed for the development (Slack 2002). Several studies investigating who ultimately pays the development charge conclude that bearer of the burden - the new homebuyer, developers or pre-development landowners - depends to a large extent on the demand and supply conditions in the market for new housing (Slack and Bird 1991).

Seattle parks and recreation board introduced and used a pro-park levy to finance greenery projects which raised $\$ 198.2$ million for parks and green spaces within eight years. Additional $\$ 1.98$ million was earned from interest income during the period. Home owners contributed significant amount for the scheme and the levy provides funds for more than 100 projects over the city (Seattle Parks and Recreation Board 2004). Urban green infrastructure could be financed by local businesses, using the method of business improvement districts (BIDs), which was originally invented in Ontario, Canada and are widely used in the US and Europe since 1960s. This method improves the availability of financing and management to commercial and industrial environments through the agreement and willingness to pay by majority of businesses who agree for an additional levy (Merket el., 2012). 


\section{International Journal of Social Science and Economic Research}

ISSN: $2455-8834$

Volume:05, Issue:11 "November 2020"

Accessibility to long term loans could help to mobilize adequate finance for green urban infrastructure investments. Bonds are the safest investment option for the institutional investors such as pension funds that provides stable yields and limited risks. Pension funds play an important role in funding infrastructure projects in major cities of USA and Australia. Green bonds are promising mechanism for cities to attract private finance which it channels for directing institutional investor capital towards green projects (Della et. al., 2011). In some countries, funding from local taxes can be directed specifically towards the management and provision of green space. Minneapolis and Seattle, USA, and Melbourne, Australia, used this mechanism (CABE 2006).

Being the health benefit of green spaces is recognized funding can be accessible from stakeholders working on health. The voluntary and not-for-profit sector is also an important stakeholder in urban green space development. For instance, in USA Indianapolis city have established partnerships with church organizations to maintain neighborhood parks, Partnerships for Parks in New York and the Boston Green Space Alliance are city-wide not- for-profit organizations that aim to support green space in their respective cities. In green space sites, business opportunities such as sponsorship and the management of sports facilities, restaurants, cafés, festivals and events are other ways in which private sector funding can be sourced. New York city, USA and England are good example in using the mentioned methods of funding. Fees and fines have also been used as a mechanism to deliver funding for green space. Curitiba, Brazil, is a good example in using fees and fines for green infrastructure funding that they applied for every tree that is felled during development two must be planted or donated to the city(CABE 2006).

\section{Research Methodology}

As described in the previous parts of this proposal this study focuses on the investigation of financing green infrastructure that helps to improve the current status of the green infrastructure of the city and to maintain its sustainability. Therefore this study describes the existing situation of financing, and explores the unused potentials for the innovative financing. To accomplish these mixed research approach is employed; that is quantitative approach is used to analyze the quantitative data such as funds mobilized and utilized for the infrastructure development and other pertinent data. Qualitative approach is used to analyze the qualitative data for instance identifying unused potentials of financing the infrastructure, opinion of different respondents, nature and characteristics of the source of finance. Then in the analysis result of qualitative data supplement the result of quantitative data and vice versa. By supplementing result of one data by 


\section{International Journal of Social Science and Economic Research}

ISSN: $2455-8834$

Volume:05, Issue:11 "November 2020"

the other mixed discussion and analysis is made. Regarding to time dimension of the research the recent five years data is used to analyze the financing trends.

Both primary and secondary types of data were used to conduct this study. The secondary data was used to obtain data which relates to funds utilized for the projects undertaken in the recent five years, spending for the administration of existing infrastructure, status and demand of the infrastructure. Different reports of the agency and city administration were reviewed to obtain the data. The primary data was used to obtain opinion of the officials on the current situations of green infrastructure financing, financing problems and alternative (potential) sources of finance. Face to face interview was used to obtain the opinion of the officials regarding the study.

The obtained data were analyzed using percentage/ratio and narrated systematically. The quantitative data were performed using excel.

\section{Result and discussions}

\subsection{Demand for the green infrastructure investment and gap analysis}

To make the overall growth of the city based on the green economic development, the city government adopted the integrated city green infrastructure strategy and policy with the ratio of 30/30/40 which means from the total land size of the city 30 percent is planned to be allocated for the road, 30 percent for green spaces and 40 percent for the construction of buildings.

The city occupies a total area of $540 \mathrm{Sq} . \mathrm{Km}$ (Addis Ababa city BOFED 2012). From the total area 13.01Sq.km is rural area and only 526.99 Sq.km in the urban category. In 2016 the green infrastructure inventory of the city show that the total green area identified is only $1.6 \mathrm{Sq} . \mathrm{Km}$. Out of the total green infrastructure inventory $833,449.3 \mathrm{~m}^{2}$ are developed, and $775,602 \mathrm{~m}^{2}$ are not developed. However the target is to make the green areas 30 percent of the total surface area of the city, which is the green area is expected to be $158 \mathrm{Sq} . \mathrm{Km}(526.99 \mathrm{Sq} . \mathrm{Km} * 0.3)$ of the city total surface area. From the green infrastructure inventory identified 48.2percent (775, 602/1, $609,051.3$ ) is not developed green areas, so the developed green area is only 0.83Sq.Km. Nearly 157Sq.Km green spaces are expected to be invested in the future. The expected future green spaces investments to reach the minimum standard show how much capital is needed for the future green infrastructure investment. The other way of measuring the adequacy of green infrastructure and to indicate the future demand of green infrastructure investment is green spaces per capita. The world health organization has suggested that every city should have a minimum of $9 \mathrm{~m}^{2}$ of green space per person for healthy living(Kuchelmeister 1998). Yet Addis Ababa provides only 0.25 square metres $(833,449.3 / 3.35$ million populations) of green space per person. Whereas the other countries evidence shows that Vienna and Singapore provides 120 and 
International Journal of Social Science and Economic Research

ISSN: 2455-8834

Volume:05, Issue:11 "November 2020"

66 square metres of green space per capita respectively(Baharash Architecture n.d.). To reach the world health Organization minimum standard and national standard the green area investment done is only 3 and 1.6 percent respectively. In addition maintenance of the already developed green spaces will also need significant capital if proper maintenance can be carried out. These evidences indicate the future huge capital requirements for green infrastructure investments.

\subsection{Financing green infrastructure}

\subsubsection{Sources of finance for green infrastructure}

The study has found from the review of the secondary sources and interview of the officials that most of the public green infrastructures in the city are provided by the government using the government budget or public sources. Only some of the green spaces are developed and maintained by the private organizations (businesses) and only few green spaces that is in front of their compounds are developed by the households. Private businesses develop the green spaces by planning to use the area to advertise their business. The spaces developed by the private businesses is squares and road sides, where is the appropriate place to advertise their business. Using the interviewed official responses and observation the study has found that the green infrastructures invested by the private organization not have uniform standards. The agency has not set the required standard that can be given to the private businesses to keep the investment at a given standards.

When the green spaces are developed by the private business they use it for the advertisement of their business without any time limitation. There is no any trial from the government to maximize benefit generated from green spaces developed by the private business, for instance setting development standard, time restriction or self-develop spaces to rent it for advertisement. Income from the advertisement can have the possibility of exceeding cost of greening the spaces. There is no system of linking expenditure with certain revenue sources.

\subsubsection{Fund utilization analysis}

As discussed in the previous paragraphs the study has found that many projects are expected to be carried out in Addis Ababa to upgrade from the current poor status of the green infrastructure. To come up from such problem one minimum step is to utilize the existing resources effectively. The following table shows the utilization of the budget allocated for the green infrastructure development and maintenance in year 2011/12-201/16. 
International Journal of Social Science and Economic Research

ISSN: 2455-8834

Volume:05, Issue:11 "November 2020"

Table 1: Budget and expenditure of green infrastructure

\begin{tabular}{|l|c|c|c|c|}
\hline Year & Adjusted budget & Expenditure & Variance & $\begin{array}{c}\text { Expenditure } \\
\text { to } \\
\text { Budget } \\
\text { performan } \\
\text { ce }\end{array}$ \\
\hline $\begin{array}{l}2011 / 1 \\
2\end{array}$ & $81,654,860.00$ & $13,550,735.27$ & $68,104,124.73$ & $16.60 \%$ \\
\hline $\begin{array}{l}2012 / 1 \\
3\end{array}$ & $67,319,553.00$ & $46,016,579.91$ & $21,302,973.09$ & $68.36 \%$ \\
\hline $\begin{array}{l}2013 / 1 \\
4\end{array}$ & $106,439,714.93$ & $44,835,618.45$ & $61,604,096.48$ & $42.12 \%$ \\
\hline $\begin{array}{l}2014 / 1 \\
5\end{array}$ & $156,756,187.86$ & $67,319,626.87$ & $89,436,560.99$ & $42.95 \%$ \\
\hline $\begin{array}{l}2015 / 1 \\
6\end{array}$ & $199,496,950.73$ & $174,786,362.64$ & $24,710,588.09$ & $87.61 \%$ \\
\hline
\end{tabular}

Source: Computed from agency financial report 2011/12-2015/16

As presented in the previous section of this study has found that the green infrastructure is at very low status. Therefore high capital allocation and investment for green infrastructure is expected. But the city allocated and used in the recent five years only the finance indicated in the above table. The interviewed officials specify that the allocated budget able the agency only to make low investment of the greenery and it is inadequate, though there is also the problem in effective utilization of the allocated budget. High resource is allocated for greenery in other countries for instance according to National audit office of England (2006) in England it was estimated that almost $£ 700$ million was spent on urban green space in 2004-05. For Addis Ababa city where only few greenery exist huge capital is required to undertake many new developmental projects (almost starting from the scratch).

One indicator of the green infrastructure status of the city is per capita green spaces, the Addis Ababa per capita green spaces is 0.25 square meter and targeted to reach 0.5 square meter by the end of GTP- II. Whereas the world standard shows that urban green infrastructure per capita is 9square meter. So to reach this point high number of new projects, maintenances and strong administration function is expected and it requires high expenditure, but surprisingly the city is not utilizing the allocated budget effectively.

Of course the data depicted in the above table shows still the budget allocated for the green 
International Journal of Social Science and Economic Research

ISSN: 2455-8834

Volume:05, Issue:11 "November 2020"

infrastructure is not utilized well, this is not due to the budget is excess or there is no developmental activities. The interviewed official states that the reason for the underutilization of the allocated budget is the green infrastructure administration agency human capacity problem to undertake many activities, the contractor and other stakeholders' capacity problem. The contractors cannot complete the project on time; there is weak follow up and administration. Therefore due to their capacity problem they unable to use this small amount of budget effectively. Good human capacity with good skill for the creativity of new idea, implementation and administration is the base for the innovative financing.

\subsubsection{Revenue from green infrastructure service collection analysis}

The revenues collected from green infrastructure services are from sources such as receipt from closed parks visitors, internal services, cemeteries service, seed sales and other sources. From these sources the lion share is collected from closed parks which contribute more than 65 percent of the total revenue of each year. But these revenues are not directly used and controlled by the green infrastructure provider; it is the revenue controlled by Addis Ababa city BOFED.

To improve the green infrastructure development and maintenance in terms of both the quantity and quality, the amount of revenue generated and used by the agency is the determinant factor. To evaluate the collection performance one method is by comparison of budget and actual revenue of the agency. The revenue collection performance of the year 2012/13 to 2015/16 is depicted in the following table.

Table 2:Revenue Collection Performance

\begin{tabular}{|r|l|l|l|}
\hline Year & Budget & Actual & Performance \\
\hline $2012 / 13$ & $3,602,966.00$ & $3,247,668.00$ & $90.14 \%$ \\
\hline $2013 / 14$ & $3,602,966.00$ & $3,617,982.00$ & $100.42 \%$ \\
\hline $2014 / 15$ & $4,277,641.00$ & $4,386,684.00$ & $102.55 \%$ \\
\hline $2015 / 16$ & $5,000,000.00$ & $5,108,531.00$ & $102.17 \%$ \\
\hline
\end{tabular}

Source: Computed from agency financial report 2012/13-2015/16

As the above table shows the revenue collection target were achieved in the fiscal period $2013 / 14$ to $2015 / 16$ and only in 2012/13 it was under performed. Achieving the plan can be considered as good on one side, but on the other side considering the quality of the plan can also be needed. The plan can have defects and cause a problem over performance. Compared to the actual revenue collection potential plan can be understated and sometimes it shows that planners 
International Journal of Social Science and Economic Research

ISSN: 2455-8834

Volume:05, Issue:11 "November 2020"

didn't understand the existing potential very well. In very recent time 2015/16 the actual revenue collected is only $\mathrm{Br} 5,108,531$ which is the highest amount of all years under analysis, but when the current market situation is taken into account this amount is not sufficient to complete one simple project. However considering only the plan performance can make the agency to be proud of the performance. This exactly shows the agency financing method sustainability is under question.

User charges are an important way to provide economic signals, both to consumers, concerning the scarcity of services, and to providers, about the demand for services that needs to be met. User fees also ration the use of existing facilities and give appropriate capital investment signals. In other words, they can reduce the demand for infrastructure: - Whenever possible, local public services should be charged for rather than given awayll (Bird 2001).

\subsubsection{Evaluating self-financing capacity of the activity}

Good financial management system makes each activity to have its own sustainable sources of revenue. When each government activity has its own financing or revenue sources it becomes easy to control, evaluate the efficiency and to make improvement on the financial capacity. The following table depicts portion of expenditure financed by own revenue of the agency.

Table 3: Self-financing capacity evaluation

\begin{tabular}{|c|c|c|c|}
\hline Year & Expenditure & Own revenue & $\begin{array}{c}\text { Revenue to } \\
\text { expenditure } \\
\text { percentage }\end{array}$ \\
\hline $2012 / 13$ & $46,016,579.91$ & $3,247,668.00$ & $7 \%$ \\
\hline $2013 / 14$ & $44,835,618.45$ & $3,617,982.00$ & $8 \%$ \\
\hline $2014 / 15$ & $67,319,626.87$ & $4,386,684.00$ & $7 \%$ \\
\hline $2015 / 16$ & $174,786,362.64$ & $5,108,531.00$ & $3 \%$ \\
\hline
\end{tabular}

Source: Computed from agency financial report 2012/13-2015/16

The revenue collection from different sources is one of the determinant factors to improve quality of services provision, expand the services and to upgrade it. Even though revenue from service is not directly used for greenery purpose, we can assume its financing capacity if it were used to finance green infrastructure expenditure. It is also possible to assume that if the city administration will decide to reuse the revenue from greenery services for greenery investment purpose. By this assumption as depicted in the above table the proportions of expenditure that 
International Journal of Social Science and Economic Research

ISSN: 2455-8834

Volume:05, Issue:11 "November 2020"

can be covered by own revenue is very low. As shown in the above table revenue collected from greenery service is less than ten percent of the expenditure for the services, this realize that almost all of the greenery expenditure is financed by the government treasury (public sources). Own revenue to expenditure percentage is at decreasing rate from 2013/14 to 2015/16 and in 2015/16it is only 3 percent of expenditure which means we are not in a position to talk about self-financing because almost all are financed by using public sources.

\subsection{Problems in financing green infrastructure}

Finance is the backbone to provide and manage green infrastructure. If there is a problem either on finance mobilization or utilization, it leads high problems on green infrastructure provision and management. Therefore assessing the problems of finance system for green infrastructure development and maintenance is very important. interview of the officials show that the problems in finance system of the green infrastructure includes underutilization of the budget, low awareness of the society about green infrastructure, revenue collection from some green infrastructure services are not directly used for the green infrastructure purposes, Shortage of skilled human, budget transfer problem, weak commitment by the government, finance not released on time, problem on Project planning and implementation, income generating idea that can be used by the agency is not evolved even in the government direction.

Interviewed officials indicate that there is no revenue sources that inflow directly to the agency for the financing of green infrastructure. For instance revenue from the public parks are not directly used for the development of the parks itself, it is directly transferred to the account of the city Bureau of finance and economic development. Lack of own revenue that used directly for the infrastructure reduces the motivation of the agency to increase the infrastructure accessibility and quality through increasing their revenue. Plan and implementation of the activity can be affected by the plan for finance, when plan for finance is determined by other authority it is difficult to match plan of the activity with the plan of the finance. However if there is own revenue used for the activity itself, the agency can improve their own revenue amount by developing different strategies and then can also increase their investment and maintenance.

\subsection{Innovative financing for the infrastructure}

Securing financing for green infrastructure requires innovative solutions that combine both public and private funds because public funds alone are inadequate in the current fiscal environment.

Innovative financing can be made in three ways, one if the revenue used previously for the other purpose is now can be used for the greenery, two if changes or improvement is made on the 


\section{International Journal of Social Science and Economic Research}

ISSN: $2455-8834$

Volume:05, Issue:11 "November 2020"

previous revenue and three if the new revenue source is created. When the green infrastructure financing of the Addis Ababa city is evaluated it is possible to apply all innovative financing approach. The reason is there is revenue source which need to be assigned directly for the green infrastructure purpose, there is revenue sources which needs improvement, and there is also revenue sources which can be created. Based on the analysis of the opinion of the respondents and other data the city can innovate its financing mechanism through; involving the private sector in the form of public-private partnerships, improve community participation, improve green development by private businesses, service charge, different stakeholders participation and loans.

There are revenue sources which have direct relation with urban green infrastructure, but are not reused for the green infrastructure investment. The interviewed officials presented that revenue collected from green infrastructure such as parks, but the revenues were not used for green development purposes. They also added that the existing public parks are in poor quality and they suggest modernizing the parks can able to generate more revenues. Improving the services and reusing the revenue from it can be one innovative mechanism according to the interviewees. The agency can also work with youth and sport affairs as they want play grounds, recreational areas, and other related spaces for the youths. Theses spaces are the type of greenery, so that the agency can get funds from this organization to develop such spaces which is the common purposes for the two organizations.

Interviewed officials have responded that there is a participation of the private business and community towards the green spaces development, but it is at very low level. Review of different record of the agency shows some green infrastructures developed by the household and private businesses. In general the financing obtained from these sources is very low compared to the existing unused potentials. Therefore effective participation of the community, private business, public-private partnership, and other organizations (including nongovernmental and not for profit organizations) will be the good potential for the future green infrastructure financing by the agency. Some distance from the compound of residential or building of the business is under the responsibility of the owner to develop by the green infrastructure, but observation in the city and interviewed officials result shows this is not effective in the city. However, this can also be innovative(potential) mechanism to use for financing the green infrastructure.

Interviewed officials stated that private businesses are interested to develop green spaces for advertisement purposes. Rent of open green spaces for advertisement can be one of the important sources of revenue for green space financing. There can also be high possibility that they are interested to use the sites in the form of rent for the agreement time. 
International Journal of Social Science and Economic Research

ISSN: 2455-8834

Volume:05, Issue:11 "November 2020"

\section{Conclusions and recommendations}

The existing green infrastructure is inadequate both by its accessibility and quality. The respondents rate the existing green infrastructure as it is at poor status. The study has found that the green infrastructure is at very low level in the city and to address this problem the commitment from the government is also not satisfactory. Compared to the World Health Organization and the ministry of urban development and housing standards the current status of the green infrastructure in Addis Ababa is less than 3\% of the standards.

Most of the city green infrastructure financing comes from public sources. Only some amount of financing made by the private business on the selected green spaces and squares where they can highly advertise their business, other government organization and community. Revenue obtained from green space is not directly used for the green space financing purposes, which is another factor diminishing the financial capacity of the green space development and that restrict to increase revenue in the future by adapting relevant financing strategies. Beside the own revenue sources can able to finance only less than 10 percent of the agency annual expenditure.

Many countries solve their financial shortage in the development and maintenance of the green infrastructure by using various innovative financing mechanisms. But in Addis Ababa it is possible to say almost the innovative financing strategies are not developed and used. Lack of good and innovative financing strategies will leave the city with its poor status of green spaces, unless some measures will be taken in short period.

Therefore, this study has implications for the agency, city administration and various stakeholders. The agency management is suggested to have proper records of the green infrastructure inventory and its condition, properly use allocated budget, make partnership with different stakeholders, hire skilled man power and train the employees and exploit an alternative (potential) source of finance. The city administration is suggested to formulate policy and enforce policy to improve sources of finance for the green infrastructure, allow the reuse of revenue collected from green infrastructure services for greenery development itself, hire skilled man power and train the employees, allocate adequate budget for the green infrastructure projects and maintenance. Finally different stakeholders such as private organizations, nongovernmental and not for profit organizations, governmental organizations and individuals are suggested to contribute for the development and maintenance of green infrastructure by understanding the enormous benefit of green infrastructure.

\section{References}

Bagherian, B. (2013). Liveable cities: How much green space does your city have? 
International Journal of Social Science and Economic Research

ISSN: 2455-8834

Volume:05, Issue:11 "November 2020"

Bird, R 2001, -Setting the Stage-Municipal and Intergovernmental Financell, In Challenges of Urban Governments, edited by M. Freireand R. Stren, Washington, DC, World Bank Institute.

CABE 2006, -Paying for parksll, eight models for funding urban green spaces, published in 2006 by the Commission for Architecture and the Built Environment.

Cohen, JK 2002, -Innovative Uses of Credit for Financing Infrastructure, Historical and Contemporary Perspectives\|, a Report Prepared for the City University Institute for Urban Systems, the City College of New York.

Countryside Agency 2006, -Countryside in and around Towns, the Green Infrastructure of Yorkshire and the Humberll, Country side Agency Leeds.

Coutts, Christopher, Mark H, and Timothy C 2010, "Using GIS to model the effectsof green space accessibility on mortality in Florida", Geocarto International.

David,McN and Matt, R 2015,-financing opportunities and needs, green infrastructure\|.EU Business and Biodiversity Platform.

Della, C Kaminker, R.C and Stewart F 2011, -The Role of Pension Funds in Financing Green Growth Initiatives\|, OECD Working Papers on Finance, Insurance and Private Pensions, No.10, OECD, Paris

Estache, Antonio, and Gine de Rus, eds. 2000, -Privatization and Regulation of Transport Infrastructure, Guidelines for Policymakers and Regulators.Washingtonl, DC, WBI Development Studies.

Hoornweg, D, Sugar, L, Lorena, C, Gomez, T, 2011b,-Cities and greenhouse gas emissions, moving forwardll, Environ Urban.

IEA 2011, -Energy for All, Financing Access for the Poorll, World Energy Outlook 2011, International Energy Agency, Paris.

Johnstone, N and Libby, W 2001,-Private Firms and Public Water,Realizing Social and Environmental Objectives in Development Countries\|, Cheltenham UK, Edward Elgar.

Kuchelmeister, G 1998,-Urban Forestry, Present Situation and Prospects in the Asia and Pacific region\|, FAO Asia-Pacific Forestry Sector Outlook Study Rome, Food and Agriculture Organization of the United Nations Forestry Policy and Planning Division. 
International Journal of Social Science and Economic Research

ISSN: 2455-8834

Volume:05, Issue:11 "November 2020"

Loxley, C, Curtin, L, and Brown, R 2002,-Crime reduction research paper series 12", Home Office.

Larondelle, N and Haase, D 2013,-Urban ecosystem services assessment along a rural - urban gradient, A cross-analysis of European citiesll, Ecological Indicators.

Martin E and Sheryn P 2012, Green Infrastructure Life support for human habitats, the compelling evidence for incorporating nature into urban environments, A review of research and literature Prepared for the Green Infrastructure Project Botanic Gardens of Adelaide

Merk, O, Saussier, S, Staropoli, C, Slack, E, and Kim, J-H 2012, -Financing Green Urban Infrastructurelll, OECD Regional Development Working Papers 2012/10, OECD Publishing,http://dc.doi.org/10.1787/5k92p0c6j6r0-en.

Ministry of urban development and housing of Ethiopia 2015, -Ethiopia national urban green infrastructure standardll, Addis Ababa.

Mitchell, R and Frank P 2007, -Green space, urbanity and health: relationships in England" J Epidemiol Community Health.

MthuliNcuben.d,-Infrastructure Deficit, Financing Needs and the Post-2015 MDG Framework in Africall.

National audit office of England 2006'-Office of the deputy prime minister, Enhancing Urban Green Spacell, printed by House of Commons

Naumann, S, McKenna, D, Timo, K, Mav P, and Matt R, 2011,-Design, implementation and cost elements of Green Infrastructure projectsll, Final report to the European Commission, DG Environment, Contract no. 070307/2010/577182/ETU/F.1, Ecologic institute and GHK Consulting.

OECD 2008, -Public-Private Partnerships, In Pursuit of Risk Sharing and Value for Moneyll, OECD, Paris.

OCED 2012,-Financing Urban Green Infrastructurell, http://www.oecd.org/gov/regional- policy/WP_Financing_Green_Urban_Infrastructure.pdf

Parsons, J 2015, -Mapping Uniformity of Park Access Using Cadastral Data within Network Analyst In Wake County Nc\|, Master's Thesis, University of Southern California. 
International Journal of Social Science and Economic Research

ISSN: 2455-8834

Volume:05, Issue:11 "November 2020"

Parry, M., Arnell, N., Berry, P, Dodman, D, Fankhauser, S, Hope, C, Kovats, S, Nicholls, R, Satterthwaite, D., Tiffin, R, and Wheeler, T 2009, -Assessing the costs of adaptation to climate changell, a review of the UNFCCC and other recent estimates, International Institute for Environment and Development and Grantham Institute for Climate Change. London. http://www.iied.org/pubs/pdfs/11501IIED.pdf. [30-09-2009].

Seattle Parks and Recreation Board 2004,-Conservation finance, the trust for public land”,http://tinyurl.com/rjmapPro parks levy, City of Seattle http://tinyurl.com/rjmap Open Space Seattle 2100 http://www.open2100.org/

Slack, E and Bird R M. 1991, -Financing Urban Growth through Development Charges\|ll, Canadian Tax Journal, Vol. 39, No. 5.

Slack, E 2002, -Municipal Finance and the Pattern of Urban Growth”, C. D. Howe Institute, Toronto.

United Nations environment program, European bank, and Reinvesting Bretton woods committee 2016, -Financing for Green Infrastructure Investmentll, Associated Event at the EBRD Annual Meeting 2016, London.

Vivien, F and Elvira M 2010, -Ethiopia's Infrastructure, A Continental Perspective\|, The World Bank, 1818 H Street NW, Washington, DC 20433 USA

Willie T 2007, -Principles of project and infrastructure financell, published in the Taylor \& Francis e-Library, 2007.

Wolch, J, Jason, B, and Joshua N 2014, -Urban green space, public health, and environmental justicell, the challenge of making cities, just green enough, Landscape and Urban Planning. 